\title{
PERAN KONFLIK PEKERJAAN-KELUARGA TERHADAP INTENSI PINDAH KERJA DENGAN PERSEPSI DUKUNGAN ORGANISASI SEBAGAI MODERATOR
}

\author{
Selfina Alimbuto ${ }^{1}$, Rostiana ${ }^{2}$ \\ ${ }^{1}$ Fakultas Psikologi, Universitas Tarumanagara Jakarta \\ Email: selfinaalimbuto@yahoo.com \\ ${ }^{2}$ Fakultas Psikologi, Universitas Tarumanagara Jakarta \\ Email: rostiana@fpsi.untar.ac.id
}

\begin{abstract}
ABSTRAK
Frekuensi lembur yang tinggi menimbulkan konflik pekerjaan-keluarga pada karyawan. Hal tersebut dapat memicu tingkat turnover yang tinggi. Penelitian ini bertujuan untuk mengetahui apakah persepsi dukungan organisasi berperan sebagai moderator antara konflik pekerjaan-keluarga dan intensi pindah kerja. Subyek penelitian ini adalah karyawan PT X yang berlokasi di Tangerang dengan jumlah responden sebanyak 81 karyawan. Metode yang digunakan dalam penelitian ini adalah metode kuantitatif dengan teknik analisis data menggunakan MRA (Moderated Regression Analysis). Hasil penelitian menunjukkan bahwa dukungan organisasi tidak berperan dalam memoderasi hubungan konflik pekerjaan-keluarga dengan intensi pindah kerja $\left(R^{2}=0,421, p=0,166>0,05\right)$. Hal ini berarti bahwa persepsi dukungan organisasi tidak dapat menjadi moderator antara konflik pekerjaan-keluarga dengan intensi pindah kerja.
\end{abstract}

Kata kunci: work family-conflict, perceived organizational support, turnover intention

\section{PENDAHULUAN \\ Latar Belakang}

Turnover atau pindah kerja pada karyawan selalu menjadi masalah besar bagi organisasi. Hal ini menjadi isu kunci, baik di psikologi organisasi maupun manajemen (Ramesh \& Gelfand, 2010). Pindah kerja sendiri diartikan sebagai keluarnya karyawan (Spector, 2016). Istilah tentang "intensi" menggambarkan suatu keinginan karyawan atau pertimbangan untuk meninggalkan sebuah organisasi (Martin Jr., 1979; Tett \& Meyer, dalam Yamazakia \& Petchdee, 2002). Intensi pindah kerja ini merupakan sebuah prediktor yang kuat untuk berhenti dari sebuah organisasi dan menjadi langkah terakhir sebelum seorang benar-benar meninggalkan organisasi tersebut (Lee \& Bruvold dalam Yamazakia \& Petchdee, 2002).

Walaupun pergantian karyawan karena intensi pindah kerja adakalanya memberikan dampak positif, misalnya karyawan yang mempunyai kualitas rendah dapat diganti, namun juga dapat berdampak buruk bagi kelangsungan perusahaan. Peneliti organisasi menunjukan bahwa turnover mengacaukan berbagai hasil terkait produktivitas (Hausknecht, Trenov \& Howard, 2009; Shaw, Gupta \& Delery, dalam Hom, Lee, Shaw \& Hauskect, 2017) dan menurunkan performa keuangan suatu organisasi (Heavey et al, 2013; Park \& Shaw, dalam Hom, Lee, Shaw \& Hauskect, 2017).

Fenomena turnover tersebut terjadi di banyak perusahaan, tidak terkecuali di PT X. PT X adalah salah-satu perusahaan yang bergerak di bidang TI di Indonesia yang berbasis proyek. Hingga saat ini PT X telah mempunyai beberapa anak perusahaan yang bisnisnya bergerak di bidang TI namun dengan jasa pelayanan yang berbeda. Selain itu, PT X juga telah membuka cabang dibeberapa negara antara lain Filipina, India dan Malaysia.

Perkembangan yang begitu cepat termasuk eskpansi ke beberapa wilayah di luar Indonesia tentu saja membutuhkan SDM dengan jumlah yang banyak dan dengan kualitas yang baik. Terlebih 
bahwa SDM merupakan modal utama dalam bisnis perusahaan ini. Oleh karena itu, turnover yang tinggi akan ikut memengaruhi produktivitas perusahaan.

Dalam kurun waktu tiga tahun terakhir yaitu tahun 2014-2016, angka turnover mencapai 14.49 $\%, 13,6 \%$ dan 21,5\%. Data tersebut menunjukan bahwa turnover yang ada di PT X tergolong tinggi dimana angkanya melebihi $10 \%$. Data yang dikumpulkan dalam proses exit interview menunjukan bahwa lembur merupakan alasan terbesar ke-empat yang membuat karyawan mengundurkan diri yaitu sebanyak 23 orang atau $11 \%$. Berdasarkan hasil wawancara yang dilakukan kepada beberapa karyawan yang jumlah lemburannya paling banyak, sebagian besar dari mereka terlibat dalam beberapa proyek sekaligus bahkan ada juga yang memegang dua posisi sekaligus. Hal ini menimbulkan dampak dimana sebagian besar waktu yang mereka miliki digunakan untuk urusan pekerjaan.

Beberapa alasan yang dikemukakan pada saat interview oleh karyawan yang mengundurkan diri maupun yang frekuensi lemburnya tinggi, didapatkan informasi bahwa oleh karena harus lembur di kantor, mereka tidak dapat mendampingi istrinya di saat-saat yang sangat dibutuhkan-seperti saat melahirkan; jarang bertemu anaknya karena ketika mereka pulang anaknya sudah tidur dan ketika merkaa berangkat anaknya masih belum bangun; tidak sempat menjenguk orang tua, tidak bisa mengikuti acara-acara keluarga dan lain sebagainya. Sejalan dengan hasil wawancara tersebut, penelitian Higgins, Duxbury dan Johnson (2000) menunjukan bahwa terdapat efek langsung dari waktu yang dihabiskan di tempat kerja terhadap konflik pekerjaan keluarga yang dihadapi oleh karyawan. Selain itu, sebanyak 13,39 \% atau sebanyak 28 karyawan mengundurkan diri karena alasan keluarga. Alasannya antara lain karena mengurus anak, melanjutkan bisnis keluarga, pulang kampung untuk menjaga orang tua dan mengikuti suami.

Keadaan yang telah disebutkan di atas merupakan suatu keadaan yang menunjukan adanya konflik antara keluarga dan pekerjaan. Hal ini dikenal dengan konflik pekerjaan-keluarga. Work family-conflict atau konflik pekerjaan-keluarga adalah suatu bentuk konflik antar peran yang mana tekanan-tekanan dari pekerjaan dan keluarga saling tidak cocok satu sama lain (Greenhouse \& Beutell, 1985). Konflik kerja-keluarga menjelaskan terjadinya benturan antara tanggungjawab pekerjaan di rumah/kehidupan rumah tangga (Frone, Russell \& Cooper, 1994).

Beberapa hasil penelitian terkait dengan konflik pekerjaan-keluarga dan intensi pindah kerja menunjukan hasil yang tidak konsisten. Misalnya, hasil penelitian yang dilakukan oleh Boyar, Maertz, Pearson dan Keough (2003) dan Ghayyur dan Jamal (2012) menunjukan adanya hubungan yang signifikan dan positif antara konflik pekerjaan-keluarga dan intensi pindah kerja. Sedangkan hasil penelitian yang lain, misalnya penelitian yang dilakukan oleh Lyness dan Thompson (dalam Eric \& Kudo, 2014) dan Ahmed (2014) menunjukan bahwa ada hubungan yang signifikan dan negatif antara konflik pekerjaan-keluarga dan intensi pindah kerja. Perbedaan hasil penelitian menunjukan adanya kebutuhan variabel lain yang turut mengatur hubungan antara kedua variabel tersebut. Variabel yang dimaksud adalah variabel moderator. Variabel ini diharapkan dapat memperkuat atau memperlemah hubungan antara konflik keluarga-kerja dan intensi pindah kerja.

Conseravation of Resource Theory mengatakan bahwa manusia memiliki sumber daya yang berusaha dipertahankan. Sumber daya itu meliputi sasaran, kondisi (status pernikahan, jabatan), karakter pribadi (nilai diri), dan energi (waktu, uang, pengetahuan). Konflik pekerjaan-keluarga adalah salah-satu akibat dari kehilangan sumber daya tersebut (Grandey \& Cropanzano, 1999). Oleh karena itu, bagi karyawan yang mengalami konflik pekerjaan-keluarga membutuhkan 
dukungan organisasi dimana ia bekerja. Dukungan organisasi yang diperoleh oleh karyawan dapat mempengaruhi psikologis dalam bekerja.

Penelitian menunjukan bahwa persepsi dukungan organisasi berkorelasi negatif terhadap konflik pekerjaan-keluarga (Foley, Hang-Yue \& Lui, 2005; Warren \& Johnson, 1995). Sejalan dengan hal itu, hasil penelitian Kahya dan Kesen (2014) menunjukan hal yang sama bahwa persepsi dukungan organisasi memiliki korelasi negatif terhadap konflik pekerjaan-keluarga. Dari hasil tersebut dapat dilihat bahwa persepsi dukungan organisasi merupakan faktor penting untuk mengurangi konflik pekerjaan-keluarga.

Persepsi dukungan organisasi sendiri merupakan persepsi karyawan mengenai sejauh mana organisasi menilai kontribusi, memberi dukungan dan peduli pada kesejahteraan mereka (Rhoades \& Eisenberger, 2002). Konsep ini berasal dari teori pertukaran sosial (social exchange theory) Blau (1964) yang mengatakan bahwa hubungan pertukaran sosial didasarkan pada anggapan bahwa sebuah niat baik akan berbalas di masa depan. Hasil penelitian Tumwesigye (2010) menunjukan adanya hubungan antara persepsi dukungan organisasi dan intensi pindah kerja di negara berkembang dimana pegawai yang merasakan bahwa organisasi mereka menghargai kontribusi dan peduli terhadap kesejahteraan mereka, menunjukan level komitmen yang tinggi dan level intensi pindah kerja yang rendah. Mendukung hal tersebut, Eisenberg dan Shanock (dalam Chaman, Ahmed, Naqvi \& Sador, 2014) mengatakan bahwa ketika organisasi mendukung karyawan maka nampaknya karyawan merasa puas dengan pekerjaan mereka dan akibatnya tidak terlihat bahwa mereka mempunyai niat untuk meninggalkan organisasi. Oleh karena itu, peneliti memasukan persepsi dukungan organisasi sebagai variabel moderator dalam penelitian ini.

Dengan adanya persepsi dukungan organisasi sebagai moderator maka diharapkan bahwa hubungan antara konflik pekerjaan-keluarga bisa lebih kuat ataupun lebih lemah. Apabila persepsi dukungan organisasi lemah, maka hal tersebut akan ikut melemahkan hubungan konflik keluarga-pekerjaan. Demikian sebaliknya, jika persepsi dukungan organisasi tinggi maka hubungan antara konflik pekerjaan-keluarga akan menjadi tinggi juga.

\section{Rumusan Masalah}

Berdasarkan penjelasan di atas maka peneliti ingin mengetahui apakah persepsi dukungan organisasi menjadi moderator terhadap peran konflik kerja-keluarga terhadap intensi pindah kerja.

\section{METODE PENELITIAN \\ Partisipan}

Partisipan dalam penelitian ini adalah karyawan di PT X sebanyak 81 karyawan dari bagian teknikal dan sales yang dalam waktu tiga tahun terakhir mengalami tingkat turnover yang tinggi baik perempuan maupun laki-laki. Partisipan ini diambil berdasarkan teknik pengambilan sampel berdasarkan kriteria (criterion sampling) dimana partisipan dipilih dari karyawan pada direktorat teknikal dan sales yang bekerja minimal 1 tahun baik laki-laki maupun perempuan. Selain itu, teknik pengambilan sampel juga berdasarkan kemudahan (convenience sampling) yaitu peneliti memilih partisipan yang tersedia dan yang bersedia untuk berpartisipasi dalam penelitian ini. Desain penelitian yang dipakai dalam penelitian ini adalah penelitian kuantitatif. Metode pengambilan data dilakukan dengan menggunakan kuisioner dan dianalisis menggunakan teknik 
analisis MRA. Adapun kriteria sampel penelitian ini adalah karyawan PT X baik laki-laki maupun perempuan pada bagian teknikal dan sales.

Gambaran partisipan dalam penelitian ini adalah sebagai berikut: berdasarkan jenis kelamin, laki-laki sebanyak 49 orang $(60,5 \%)$ dan perempuan sebanyak 32 orang $(39,5 \%)$. Berdasarkan pendidikan terakhir, Pendidikan SMK sebanyak 19 orang $(23,5 \%)$ dan sarjana sebanyak 62 orang (76,5\%). Berdasarkan status pernikahan, berstatus menikah sebanyak 35 orang (43,2\%), belum menikah sebanyak 45 orang $(55,6 \%)$ dan duda/janda sebanyak 1 orang $(1,2 \%)$. Berdasarkan jumlah anak, belum mempunyai anak sebanyak 55 orang $(67,9 \%)$, mempunyai 1 orang anak sebanyak 12 orang (14,8\%), mempunyai 2 orang anak sebanyak 12 orang $(14,8 \%)$ dan mempunyai 3 orang anak sebanyak 2 orang (2,5\%). Berdasarkan level pekerjaan, junior staf sebanyak 21 orang $(25,9 \%)$, senior staf sebanyak 26 orang $(32,1 \%)$, section head sebanyak 9 orang $(11,1 \%)$, department head sebanyak 13 orang (16\%) dan group head sebanyak 12 orang $(14,8 \%)$. Berdasarkan adanya aktivitas diluar pekerjaan, 47 orang $(58 \%)$ memiliki aktivitas dan tidak memiliki aktivitas sebanyak 34 orang (42\%).

\begin{abstract}
Alat ukur
Work family conflict atau konflik pekerjaan-keluarga diukur dengan skala yang telah dikembangkan oleh Fakultas Psikologi Untar berdasarkan konsep dari Nettemeyer, Boles dan Mc. Murian (1996), Burley (1989), dan Carlson, Kacmar, dan Williams (2000). Alat ukur ini terdiri dua dimensi yaitu dimensi work to family conflict dan family to work conflict. Seluruhnya terdiri dari 36 butir item pertanyaan yang semuanya adalah butir pertanyaan positif. Hasil uji reabilitas menunjukan bahwa dari kedua dimensi variabel yaitu work to family conflict dan family to work conflict, keduanya memiliki Cronbach Alpha masing-masing 0,930 dan 0,911.
\end{abstract}

Pengukuran variabel turnover intention atau intensi pindah kerja pada penelitian ini menggunakan alat ukur yang dikembangkan oleh Fakultas Psikologi Untar yang diadaptasi dari Cohen (1999), Jung dan Yoon (2013), Martin dan Hafer (1995). Alat ukur tersebut terdiri dari 10 item pertanyaan yaitu 4 butir negatif dan 6 butir positif. Hasil uji reabilitas, nilai Alpha Cronbach adalah 0,886 .

Variabel perceived organization support atau dukungan organisasi diukur skala yang diekembangkan oleh Fakultas Psikologi Untar yang diadaptasi dari alat ukur POS yang disusun oleh Eisenberger, Hutington, Hutchison dan Sowa (1986). Hasil uji reabilitas menunjukan bahwa dari ketiga dimensi variabel yaitu fairness, supervisor support dan reward and job condition masing-masing memiliki Alpha Cronbach 0,825, 0,834 dan 0,754.

\title{
3. HASIL DAN PEMBAHASAN
}

Untuk pengujian hipotesis dilakukan langkah-langkah sebagai berikut. Pertama adalah melihat peran konflik pekerjaan-keluarga terhadap intensi pindah kerja. Untuk tujuan tersebut peneliti meregresikan $z$ score konflik pekerjaan-keluarga dengan $z$ score intensi pindah kerja. Hasil dari nilai regresi kedua variable ini menunjukan bahwa konflik pekerjaan-keluarga mempunyai peran terhadap intensi pindah kerja $\left(R^{2}=0,221 ; p=0,000<0,01\right)$

Langka ke-dua yang dilakukan adalah menambahkan variabel persepsi dukungan organisasi sebagai moderator antara konflik pekerjaan-keluarga dan intensi pindah kerja. Hasil perhitungan menunjukan bahwa persepsi dukungan orgaisasi tidak signifikan berperan sebagai moderator terhadap konflik pekerjaan-keluarga dan intensi pindah kerja $\left(R^{2}=0,421 ; p=0,166>0,005\right)$. Hal ini 
berarti bahwa persepsi dukungan organisasi tidak mampu memoderasi hubungan antara konflik pekerjaan-keluarga dengan intensi pindah kerja.

Jika ditinjau dari rerata dukungan organisasi pada sampel penelitian ini (mean=2,7675) dimana hal ini menunjukan bahwa dukungan organisasi yang dirasakan karyawan rendah. Hal inilah yang menjadi alasan mengapa dukungan organisasi tidak dapat berperan sebagai moderator antara konflik pekerjan-keluarga dengan intensi pindah kerja. Selama ini kebanyakan dari karyawan merasa bahwa tidak mendapatkan gaji yang sesuai. Selain itu, karyawan juga merasa bahwa atasan tidak mendukung baik dalam urusan pekerjaan ataupun ataupun urusan personal bawahannya. Demikian juga, dukungan organisasi juga dirasa rendah dalam hal memfasilitasi karyawan dalam pengembangan karir dan juga pengembangan diri karyawan.

Hasil penelitian ini sejalan dengan hasil penelitian Chaman, Ahmed, Naqvi dan Sandor (2014) menemukan bahwa persepsi dukungan organisasi tidak signifikan berperan sebagai moderator antara konflik pekerjaan-keluarga dan intensi pindah kerja. Hal tersebut terjadi dikarenakan organisasi tidak melibatkan karyawan dalam proses pengambilan keputusan dan mereka merasa tidak bernilai oleh organisasi. Alasan lainnya karena tidak ada pengembangan karir dan pengembangan diri juga budaya favoritism dimana hal tersebut berdampak pada karyawan merasa bahwa kesejahteraan mereka di abaikan.

Sementara persepsi dukungan organisasi terbukti mempunyai korelasi negatif yang signifikan terhadap intensi pindah kerja. Jika persepsi dukungan organisasi tinggi maka intensi pindah kerja menjadi rendah ataupun sebaliknya. Selanjutnya pada konflik pekerjaan-keluarga juga menunjukan peran langsung yang signifikan positif terhadap intensi pindah kerja. Ini artinya bahwa apabila konflik pekerjaan-keluarga tinggi maka intensi pindah kerja juga menjadi tinggi dan demikian sebaliknya.

Mempertimbangkan hal tersebut di atas maka persepsi dukungan organisasi lebih cocok dijadikan sebagai prediktor daripada sebagai moderator. Demikian juga konflik pekerjaankeluarga dapat dijadikan variabel prediktor tanpa menggunakan variabel persepsi dukungan organisasi sebagai moderator.

Selain itu, keterbatasan dalam penelitian ini yaitu bahwa jumlah responden penelitiannya hanya 81 orang sehingga efek interaksi pada variabel tidak dapat dilihat. Selain itu, penelitian ini tidak bisa digeneralisasikan oleh karena sampel yang digunakan hanya dari PT X. Sehingga sebaiknya pada penelitian selanjutnya disarankan untuk memperbanyak sampel penelitian.

\section{KESIMPULAN DAN SARAN}

Berdasarkan hasil pengolahan data diperoleh bahwa persepsi dukungan organisasi terbukti tidak dapat berperan sebagai moderator hubungan antara konflik pekerjaan-keluarga dan intensi pindah kerja.

Untuk penelitian selanjutnya disarankan agar dapat menduplikasi penelitian ini untuk mengetahui konsistensi hasil penelitian pada perusahaan yang berbeda mengingat hasil penelitian ini tidak dapat digeneralisasikan pada perusahaan lain. Penelitian selanjutnya juga disarankan untuk menggunakan persepsi dukungan organisasi sebagai prediktor pada intensi pindah kerja daripada sebagai moderator. 
Sekalipun hasil penelitian ini menunjukan bahwa persepsi dukungan organisasi tidak signifikan menjadi variabel moderator namun hasil penelitian ini menunjukan bahwa persepsi dukungan organisasi secara langsung berkorelasi negatif terhadap intensi pindah kerja. Hal ini berarti bahwa semakin tinggi persepsi dukungan organisasi yang dirasakan karyawan maka intensi pindah kerja semakin rendah. Adapun hasil penelitian menunjukan bahwa persepsi dukungan organisasi yang dirasakan oleh karyawan pada PT X rendah. Mengenai hal ini maka peneliti berikan saran kepada perusahaan yaitu melakukan perbaikan pada kebijakan-kebijakan perusahaan atau membuat program untuk memperkuat persepsi dukungan organisasi yang dirasakan karyawan sehingga dapat menurunkan intensi pindah kerja. Hal ini bisa dilakukan misalnya dengan melakukan evaluasi terhadap sistem imbalan yang ada saat ini, merancang program pengembangan karir karyawan secara jelas dan menjalankannya dengan baik dan juga melatih para atasan sehingga dapat berfungsi dengan baik sebagai seorang atasan.

\section{Ucapan Terima Kasih}

Terima kasih kami ucapkan kepada PT X yang mengijinkan peneliti untuk mengambil data. Terima kasih juga peneliti ucapkan untuk seluruh partisipan dan Head of Human Capital atas ijin yang diberikan kepada peneliti untuk melakukan pengambilan data.

\section{REFERENSI}

Ahmed, H. (2014). Examine the relation between workfamily conflict and its impact on job satisfaction leading to turnover. Journal of Business and Management, 16(7), pp. 73-78

Boyar, S. S., Maertz, C.P., Pearson, A.W., \& Keough, S. (2003). Work-family conflict: a model of linkages between work and family domain variables and turnover intentions. Journal of Managerial Issue, 175-190.

Chaman, S., Ahmed, S., Navqi, R., \& Sandor, T. (2014). Combined effect of work family conflict and perceived organizational support on teacher's turnover intention. International Journal of Multidisciplinary Thought, 04, pp. 631-644.

Erdogan, B. \& Enders, J. (2007). Support from the top: supervisor's perceived organizational support as a moderator of leader-member exchange to satisfaction and performance relationship. Journal of Applied Psychology, 92(2), pp. 321-330.

Eric, D \& Kudo, K.L. ( 2014). The moderation effect of status on work-family conflict-turnover intention relationship. International Journal and Management Review, 2(2), pp. 1-6.

Ghayyur, M., \& Jamal, W. (2012). Work family conflict: A case of employes turnover intention, International Journal of Social Science and Humanity, 2 (3), pp. 168-174

Grandey, A.A., \& Cropanzano, R. (1999). The conservation of resource model applied to ork family-conflict and strain. Journal of Vocational Behavior 54, pp. 350-370.

Greenhaus, J. H., \& Beutell, N.J. (1985). Source of conflict between work and family roles. Journal of Academy of Management Review, 10, pp. 78-88.

Hom, P. W., Lee T.W., Shaw, J.D., \& Hausknecht, J.P. (2017). One hundred years of employee turnover theory and research. Journal of Applied Psychology. Advance online publication.

Kahya, C \& Kesen, M. (2014). The effect of perceived organizational support on work to family conflict: a turkish case. Research Journal of business and Management, 1(2). Pp. 139148 
Malik, S. \& Noreen, S. (2015). Perceived organizational support as a moderator of affective well-being and occupational stress among teachers. Pakistan Journal of Commerce and Social Science, 9(3), pp. 865-874.

Ramesh, A \& Gelfand, J.M. (2010). Will they stay or will they go? the role of job embeddedness in predicting turnover in individualistic and collectivistic cultures. Journal of Applied Psychology, 95(5), pp. 807-823.

Rhoades, L. \& Eisenberger, R. (2002). Perceived organizational support: a review of literature. Journal of Applied Psychology, 87(4), pp. 698-714.

Yamazakia, Y. \& Petchdee, S. (2015). Turnover intention, organizational commitment, and specific job satisfaction among production employee in thailand. Journal of Business and Management, 4(4), pp. 22-38. 